\title{
Assessing the work engagement, work practices and work performance in banks
}

\author{
Salman Bashir Memon ${ }^{1 *}$, Shahrukh Baig Soomro ${ }^{2}$, Santosh Kumar ${ }^{3}$ \\ 1, 2, 3 Shah Abdul Latif University, Khairpur, Pakistan
}

\section{Keywords \\ Work engagement \\ Work practices \\ Work performance}

Received: 21 March 2018

Accepted: 26 April 2018

Published: 6 June 2018

\begin{abstract}
This study aims to measure the importance of work engagement, high work practices, and their impact on employees' work performance in the banking sector. This thesis was examined three variables, work engagement, work practices, and work performance. In order to achieve this objective, this research adopted a quantitative approach. A convenience sampling technique was used, and a survey questionnaire was based on closed-ended questions and 06 scales. A total of 150 questionnaires was distributed, and 127 valid responses were collected. Data were analyzed using Statistical Package for the Social Sciences (SPSS). To find out the result, Regression and Correlation test techniques were used. The study's key findings propose that there is a significantly positive link between work engagement, work practices, and work performance. The conclusion of this examination might be very helpful for the Banking sector to improve the performance of their employees by keeping highly engaged in work and high involvement of work practices that contribute to the achievement of the organization and employee's accomplishment.
\end{abstract}

(C) 2018 The Author(s). Published by TAF Publishing.

\section{INTRODUCTION}

\section{Background}

In a modern world of changing business environment, every organization wants to become highly effective and efficient to gain a competitive advantage. Today, organizations are practicing high performance work system as well as enhancing the level of employee satisfaction than previous work system and environment. A crucial element of any organization is its employee; it is usually recognized that human resource is the main asset of an organization. Basically, the victory of organization relies upon how human resource efficiently performs to achieve goals and objectives of the organization. Therefore, it is important to consider the factors affecting employee's performance.

In changing climate environment, economically high unemployment rate and high rate of turnover ratio are major challenges to find loyal employees. Mostly, organizations focus on its employees to attract, retain, and engage them to achieve organizational goal as well as boost productivity level. Nowadays, employee engagement is considered as one of the most powerful tools to measure the level of outcomes of organizations towards its vision, mission, and core values. Generally, engagement refers to the level of commitment and/or involvement. Engaged employees are considered as motivated, positive, inspired, and having a great sense of feeling attached to the job and manager. They work with flexibility and utilize skills on job to perform energetically with their subordinates, colleagues, co-workers, and supervisors toward organizational mission.

According to the study of W. B. Schaufeli, Salanova, González-Romá, and Bakker (2002), he indicates that work engagement is categorized as "a positive, fulfilling, workrelated state of mind that is characterized by vigor, dedication, and absorption". Kahn was the first researcher who quoted work engagement "the harnessing of organization members' selves to their work roles; in engagement, people employ and express themselves physically, cognitively, and emotionally during role performances" (Kahn, 1990; Na Ayutthaya, Tuntivivat, \& Prasertsin, 2016; Pahayahay, Asejo, Pangan, Dasig Jr., \& Panganiban Jr., 2017). In ad-

\footnotetext{
${ }^{*}$ corresponding author: Salman Bashir Memon
}

†email: salman.memon@salu.edu.pk 
dition, highly engaged employees are mutually connected cogitatively, emotionally, and physically. In some situations, work engagement is anything but difficult to perceive and very hard to characterize. Despite this, the importance of work engagement is increasing day by day as it has appeared to be a source of employee motivation.

Work performance is the result of accomplished tasks and performed work assignments (Cardy, 2004; Chong \& Lee, 2017; El-Ghalayini, 2016). It can be termed as an active work plans that needs to be accomplished within deadlines. However, performance assessment is a fundamental part of performance management. Delery and Doty (1996) is main contributor who articulated that performance of any employee is directly linked with overall organizational activities and daily practices which requires proper configuration. In other words, configuration between organizational activities and daily practices need HR planning in order to accomplish hierarchical objectives. According to Macey and Schneider (2008), Mone and London (2018), employee engagement is a key determinant of employee performance. It is further mentioned that performance has three attributes which are ability, opportunity and motivation (Ivancevich, Matteson, Freedman, \& Phillips, 1990; Warizin, 2017). Ability is a capability of doing something with proper skills, education and experience. Opportunity is related to grabbing the chance for progress in future, and lastly motivation is the desire to attain a goal by putting efforts. As indicated by dynamic human asset point of view, 'High Performance Work Practices (HPWP)' includes strengthening, examination framework and preparing impact the authoritative and representative execution. For better execution, representatives ought to be propelled from superior work practices. Workers are propelled when they are given specialized tasks and when they take part in preparing programs along with deserve monetary returns for their endeavors.

In the literature, high-performance can be assessed and classified through three ways. These factors are employee consciousness, accessibility and employee observation. Although, there is a direct influence of these variables on performance (Punia, Garg, \& Garg, 2014; Sharma et al., 2015). According to the Rousseau and Greller (1994), the beginning of twenty-first century has embarked with the remarkable development in term of measurement of human asset since the idea of HPWP and their effect has changed that way employee performance and business results. The impact has been witnessed in increasing efficiency, productivity, less staff turnover, enhanced cooperation, advanced preparing and capacities, more notable staff duty and sophisticated rewards to the employees. HPWS encourages a 'win-win' situation. Kramar (2014) inferred that HPWP may prompt innovativeness, execution and reliability among workers.

In terms of policies and practices, previous research argues a very diverse HRM perspective which has significant impact on the performance of the organization that how the human capital efficiently utilized can improve organizational productivity. The most significant practice on which organization achievement rely is the best possible administrative approaches and performance examination framework (Murphy \& Margulies, 2004) which exclusively sours the performance of the employee.

According to many researchers Bakker, Demerouti, De Boer, and Schaufeli (2003), Bakker, Schaufeli, Leiter, and Taris (2008), W. B. Schaufeli, Bakker, and Van Rhenen (2009), HR practices play significant role between employee engagement and their performance. HR focuses on basic workplace environment that stimulate workers thru offering them improved work conditions. In accordance with ideas of self-rule and adaptable job framework, presentation of elite effort sharpens (HPWP from now on) an emphasis on enabling employee and furnishing them with rewards and recognition.

\section{Problem Statement}

The success and failure of any organization is dependent upon the workforce, and it is accepted by most of the researchers that manpower is the backbone of any organization. Having the efficient workforce helps organization to grow in global market by accepting the new challenges and risk of the environment. In recent years, employees comfort at work has been perceived as a vital component for measuring their profitability. Employee engagement influence the quality of banking service with resulting impact on consumer loyalty and extreme performance. Subsequently, many firms strive to make high engagement among their workers. Engaged employees exhibit qualities of dependability, trust and sense of duty with their organization. Employee engagement being a significant factor for employee productivity, there is an experimental study that has been directed as topic in connection to banking sector of Pakistan. Keeping in mind the end goal to make a situation, it is essentially vital to know the impact of work engagement and work practices on employee performance in banking sector of Pakistan. 


\section{Significance of Study}

In modern world of globalization amid growing competition and increased pace of technology, new challenges, day by be advancement in practices, changing culture and working environment, organization(s) need to energetic, competitive, self-motivated, and highly engaged in which employees utilize their unutilized competencies, skills at full capacity and create ideas to get work done efficiently to achieve organizational strategic mission, vision and goal(s). These achievements can only be attained by employees who are the main asset of organization. Therefore, it is not possible without employee effective performance. Whenever; performance is discussed it directly refers to working conditions, working environments, working daily practices and engagement toward employee performance. Work engagement and work practices are important factor to enhance employee performance. Literature of various related studies also support this conviction that work engagement, work practices and work performance is the main source of organizational productivity.

\section{Research Aims and Objectives}

The purpose of this research is to know the level of work engagement, involvement of work practices and outcomes of employee performance in banking sector. Accordingly, there is a need for pervasive research studies that thoroughly evaluate how work engagement and work practices effect on the work performance within the banking sector. Therefore, this study has following aims and objectives.

\section{Research Aims}

- To examine the relationship of work engagement and work performance in banking sector.

- To examine the relationship of work practices and work performance in banking sector.

\section{Research Objectives}

- To study the literature on topic of assessing work engagement, work practices and work performance in the banking sector.

- To design a methodology for exploring the significant relationship among the level of work engagement, custom of work practices and the work performance at banks.

- To create a research instrument for data collection, depending on the appropriate models for measuring work engagement and work practices relationship with employee performance.

- To identify the views of bank employees on work engagement, work practices and work performance.

- To distinguish the main trends among relationship between work engagement, work practices and work performance in banking sector dependent on the primary data analysis.

- To suggest recommendations for banking sector toward enhance employee performance.

\section{LITERATURE REVIEW}

\section{Engagement}

According to the Jeung (2011), "engagement is like an old wine in a new bottle". Many organizations have intellectua-

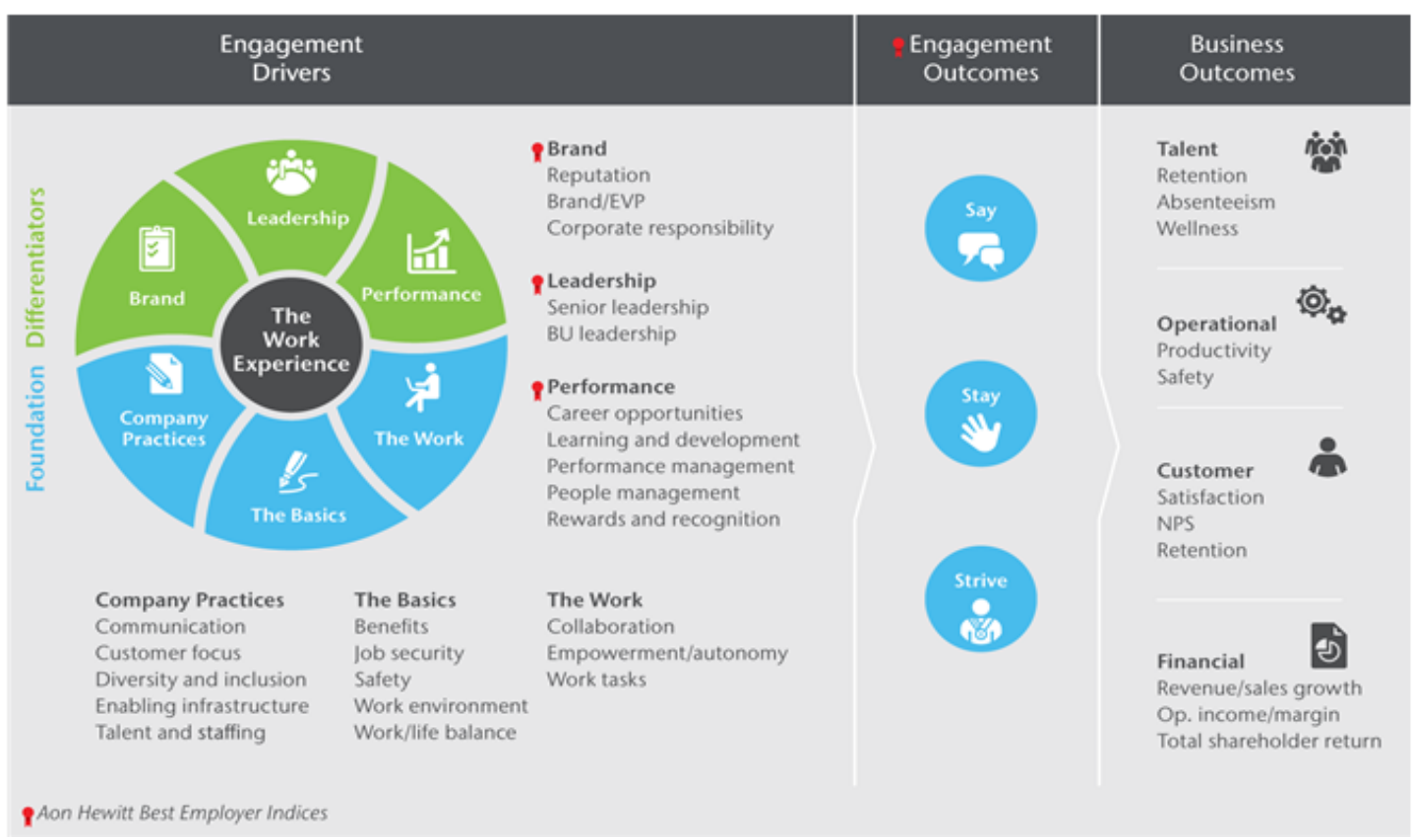

FIGURE 1. Testing hypothesis 
lized engagement through joining and depending on existing thoughts. For example, duty, fulfillment, inclusion, inspiration, and extra role execution. For example, as indicated by Mercer, "employee engagement-too called "responsibility" or "inspiration"-indicates to a spiritual state wherever workers sense a personal stake in the organization's prosperity and accomplish to an elevated expectation that possibly will surpass the expressed prerequisites of employment. In addition, the Hewitt Associates LLC (2004) categorized engagement in three modes. i) Say i.e., reliably talk emphatically regarding the association to colleagues, potential staffs, and clients; ii) Stay i.e., need to became an specific from the firm regardless of probabilities to work everywhere otherwise; iii) Strive i.e., put on extra time, energy, efforts and role play toward achievements of business outcomes.

\section{The Needs-Satisfying Approach}

According to Kahn (1990) employee engagement characterized as the multidimensional state in which they are physically, intellectually, deeply, and rationally while role performance. Few other researchers May, Gilson, and Harter (2004) concludes that engagement as the professional and behavioral appearance of one's favored self-task. Although, critical for the theoretic planning engagement, the 'needs-satisfying' methodology has been utilized in a practical study.

\section{The Burnout-Antithesis Approach}

Well-known in psychological state of health research, this approach fathoms work engagement as opposite o burnout. For instance, Maslach and Leiter (1997), Spector, Dwyer, and Jex (1988) said that engagement and exhaustion both are the positive and negative close opinions of a solitary range. In addition, engagement is described through vitality, contribution and adequacy, which are viewed as per the immediate alternate extremes of the three burnout measurements namely, fatigue, pessimism and absence of achievement. The second, elective interpretation reflects that work engagement as an idea that is adversely identified with burnout. As per view of Fred and Suzanne (2002), W. B. Schaufeli et al. (2002) 'work engagement' is characterized as encouraging, satisfying, business linked perspective that is described by vigor, devotion, and adaptation. Whereas; vigor states that large amounts of vitality and psychological versatility though working, the readiness to put force in one's work, and perseverance even in the face of challenges and devotion categorically required in one's work for encountering a feeling of significance, eagerness, motivation, pride, and challenge. Retention refers to being completely focused and joyfully immersed in one's work, whereby time passes rapidly and one experiences issues with confining oneself from work.

\section{The Satisfaction-Engagement Approach}

Gallup organization and many researchers Harter, Schmidt, and Hayes (2002) quote employee engagement as an "individual's involvement and satisfaction with as well as enthusiasm for work". According to the Gallup's definition on engagement 'engagement is an integrated and well-known theory such as, involvement and satisfaction of jobs. This is outlined with method that, in the wake of controlling of estimation mistake, Gallup's Q12 associates perfectly with single thing that beats satisfaction of job, indicating that both are basically vague. The researcher Harter et al. (2002) recognize this cover by expressing that the Q12 surveys" "antecedents to positive affective constructs such as job satisfaction". Buckingham and Coffman (2014) said contrasting to the experience of engagement as far as contribution, fulfillment and energy, the Q12 measures the "antecedents" of engagement as far as saw work assets. The purpose behind that will be that the Q12 has been expressly planned from a significance viewpoint and not from an academic point of view. According to Harter et al. (2002) at the last, the Q12 was first and first outlined as apparatus for administration in the direction of enhance occupations with the goal that employees will be additional fulfilled. In any case, the Satisfaction-Engagement approach has a massive effect in the scholarly community also, because Gallup's investigation has set up important connections between employee engagement and specialty unit results, for example, consumer loyalty, benefit, efficiency, and turnover.

\section{The Multidimensional Approach}

According to researcher Saks (2006) he categorized engagement in components "a distinct and unique construct consisting of cognitive, emotional, and behavioral components that are linked with individual role performance". Similarly, to Kahn (1990) definition it likewise concentrates on performance by work. The imaginative viewpoint is that Saks (2006) recognizes "work engagement" (playing out the work part) and "hierarchical engagement" (playing out the part as an individual from the association). While together they are linked, they appear to have changed precursors and outcomes. By combining these four methods respectively concern another engagement part; (i) it directs relation with performance; (ii) it is constructive in nature regarding of employee prosperity rather than burnout; (iii) 
its significant relation of resourcefully works; (iv) its direct connection to both job and organization. Apparently, the greatest imperative issue while characterizing engagement is "where to draw a line" or else then again put in an unexpected way, which components is to include and which components is to exclude from the meaning of engagement. Schneider and May (1995) proposed a wide-ranging combination of components which has been utilized to characterize the engagement. Their reasonable system for thoughtful employee engagement integrates: (i) characteristic engagement (e.g., good faith, quality, significant effect, ac- tive identity); (ii) state engagement (e.g., fulfillment, attachment, strengthening); and (iii) behavioral engagement (e.g., additional part conduct, proactivity, part extension). Subsequently, Saks (2006) has noted in his analysis, for (Schneider \& May, 1995) "engagement" is like an umbrella everyone can take this as who is needed. Interestingly, W. B. Schaufeli and Bakker (2010) illustrated a more prohibitive research towards reflects of work engagement as an accomplished mental stage which mediates the effect of occupation assets and individual assets on administrative results.

TABLE 1. Communication of engagement

\begin{tabular}{ll}
\hline \hline May et al. (2004) & W. B. Schaufeli et al. (2002) \\
\hline Physical engagment & Vigor \\
"I exert alot of energy performing my & $\begin{array}{l}\text { "At my job, I feel I am brusting with } \\
\text { energy" }\end{array}$ \\
job" & $\begin{array}{l}\text { Dedication } \\
\text { Emotional engagment }\end{array}$ \\
"I really put my heart into this job" & "I am enthusiastic about my job" \\
Cognitive engagment & Absorption \\
"Performing my job is so absorbing that & " When I am working, I forget every \\
I forget everything else" & thing, around me" \\
\hline \hline
\end{tabular}

Subsequently, not at all like Schneider and May (1995), who exhibit comprehensive systematic categorization which shelter full scope of conceptions which somehow been related by engagement. Figure 2 illustrates the involvement of work engagement after its apparent precursors in addition outcomes. This indicates that not one or the other clever occupations (as per satisfaction-engagement approach) nor representatives' accomplishment conduct (as per the business approach) that are considered in place of establishing segments of work engagement. Apparently, these precursors and results possibly will (also should) stay combined into examination and practical activity, yet they are supposed to be a particular ideas.

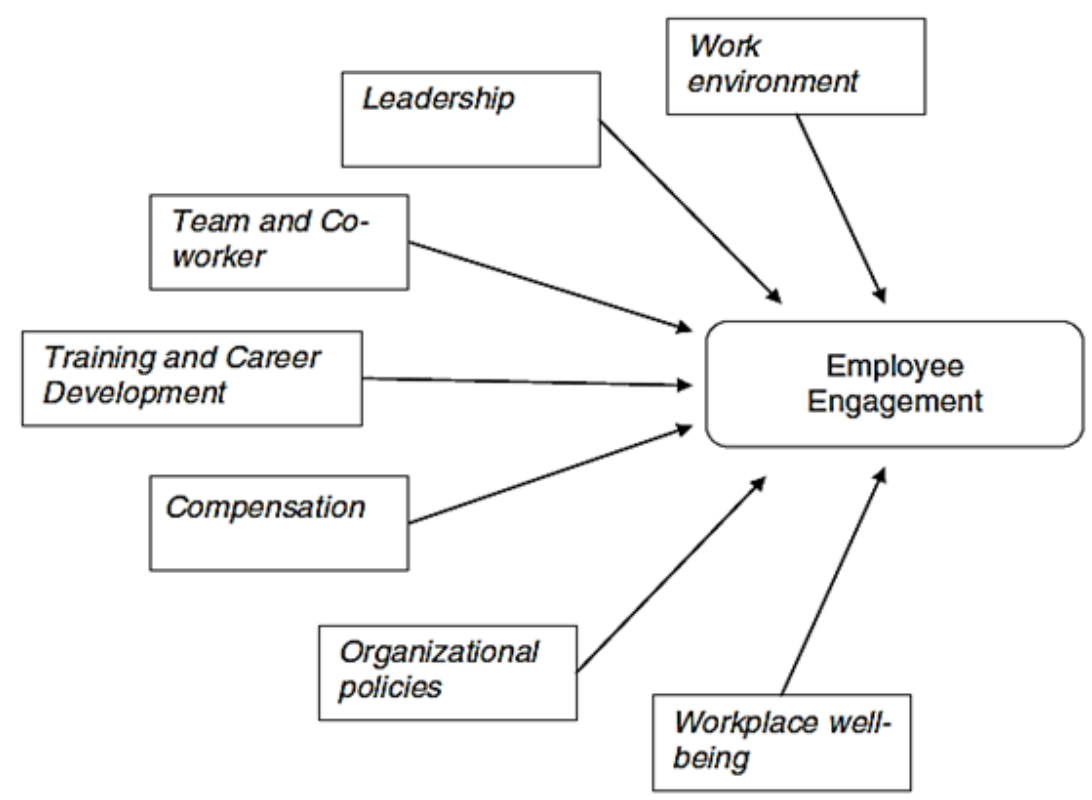

FIGURE 2. Factors toward employee engagement 
For instance, a vocation could be ingenious yet worker won't not feel associated with due to personal matters. Alternatively, a worker may sense drew in yet not indicate activity (i.e., additional part conduct) in light of imperatives on work. As per these two cases show, the understanding of work engagement is nor innately linked to testing work nor to performance and ought to subsequently remain distributed with as a dissimilar element. Applying a metaexamination that comprised further than 200 hundred articles. As Christian, Garza, and Slaughter (2011) efficiently tried a relative model, as is delineated in (Figure 2). They included independence, undertaking assortment, assignment centrality and input as occupation assets and principles and constructive effect as individual assets. Moreover, transformational initiative was incorporated that directly affected in-part and extra role execution and additionally an aberrant impact over work engagement. Thus, it appears that model (Table 1) was upheld through experimental study. In addition, meanings of engagement as per spiritual state said by Kahn (1990), W. B. Schaufeli et al. (2002) appropriate, together scholastic thoughts concur that engagement involves a physically-energized (vigor), an emotional (dedication), and a cogitative (absorption) part. The similarity of these both definitions delineated via their operationalization. Seeing the work of these Kahn (1990), May et al. (2004) as per these researchers built up an engagement stock that covers of three dimensions: subjective, enthusiastic and physical involvement. Things which are combined in this stock determine a hiding similarity through those incorporated into the assimilation, commitment, and energy sizes of the UWES individually. He showed up especially that the subjective engagement and retention scales are emphatically connected, while the physical engagement and the force scales are just feebly linked, to enthusiastic engagement and commitment scales some place in the middle of as per said by Viljevac, Cooper-Thomas, and Saks (2012). As of late, furthermore expanding on the efforts of Kahn (1990) the logical, societal, emotional engagement measure was presented. They categorized features of engagement level: (i) scholarly (level of mentally involved in his work), (ii) societal (level of being more social with others towards shares values with co-workers and well connected with workplace) and last (iii) full of feeling (level to which one encounters a state of supportive influence identifying with someone's work role). As per above three level of state first level represent to absorption while second level represent the energy and last third level has not been measured some time.
According to another researchers Anitha (2014) they demonstrate that there are six management capacities augmented due to significant factor engagement. For example, work contented (self-determination, open door of challenging learning), remuneration/fiscal advantages (interesting compensation as compared to competences and commitment, sufficient salary for job and within-organization fairness), work and life adjustments (active around distinct needs, always prepared for family time spending), top hierarchy management worker relationships (approachability of top level, their abilities and ethical lead, stability in behavior, concerning with perceptions of juniors, giving a domain of liaising), opportunity for improvement and career growth (strategic strategy, satisfactory reorganization policy for profession growth and headway, unmistakably growth of settle down career; accomplishment of the development strategy in a realistic and straightforward mode, which help towards workforces in effecting change) and team work (significance, contribution sandwiched by intodivision of groups). The current examination thoroughly focusses on the diverse elements of employee engagement.

\section{Factors of Employee Engagement}

As per above perspectives, this study intended to examine several factors that endowed with Khan's definition of three psychological states of employee engagement. As illustrated in Figure 2, there are several determinants of engagement starting from work environment to workplace well-being along with important characteristic that support measurement of employee engagement.

\section{Work Environment}

Work environment is basic part of employee engagement. According to Harter et al. (2002), Holbeche and Springett (2004), May et al. (2004), Rich, Lepine, and Crawford (2010) high level of engagement is a result of workplace environment. In addition, Cartwright and Holmes (2006), Deci and Ryan (1987) specified that organization needs to show concern about their employee needs and their feelings by providing them important feedback and empower them to share their level of stress. It also produces new capacities to face new challenge. Hence, meaningful workplace divert employees focus toward increasing performance and engagement.

\section{Leadership}

Leadership assumed to be a second important factor to influence employees toward engagement. According to 
Walumbwa, Avolio, Gardner, Wernsing, and Peterson (2008) positive and strong leadership is multitasking force which generate awareness, balanced method of communication and handling of information, social openness, and moral standards. According to both Wallace and Trinka (2009), Xu and Cooper Thomas (2011) they describes that level of engagement happens when leaders are motivating about work. Leaders are supposed to be accountable and required to communicate tit for tat for their efforts to organizational success. Apparently, when employee performance recognized as an important source of organizational success, it sours interest and engagement. Similarly, faithful and effective leadership may influence employee involvement, satisfaction and motivation to be engaged in work (Macey \& Schneider, 2008).

\section{Team and Co-worker Relationship}

This is another perspective that underlines team and coworker relationship. Kahn (1990) in his study found that supporting trust between relationship and team work encourage work engagement. A supporting environment always play an effective role in employee performance with responsibility. Supportive workplace gave rise to extra opportunities of learning new things without any undesired fear. According to May et al. (2004), being connected toward workplace had a great influence on employee engagement. Locke and Taylor (1990) showed that individuals who have valuable social collaboration with their associates help out other coworkers to understand imperative work activities. If employees have better relationships with their workers they are thought to be highly engaged.

\section{Training and Career Development}

$T \& D$ is a basic element to be considered in the process of engagement of employee. Trained employees are more accurate as said by Paradise (2008). Whenever; an employee is under training and development process they are thought to be more engaged and feel satisfied. According to Alderfer (1972) he contributes that if any organization give you a chance to grow professionally, it should upheld and implement the reward system. To lead the road of success organization need to undertake training and development sessions of employees and that will increase the level of engagement.

\section{Compensation or Remuneration}

Pay or compensation is a key element of engagement that impels an employee to achieve progressively and put extra miles on work performance by self-change. It integrates both cash related (i.e., increase in pay slip) and non- budgetary prizes (i.e., bonuses). According to the research by Saks (2006) affirmation and prizes are great indicators of worker engagement. They saw that when representative get prizes and affirmation from their organization they will feel obliged to respond with more raised attitude of engagement. In addition, Kahn (1990) emphasized that worker's level of engagement is a segment of their perspective of the preferences they get.

\section{Organizational Polices}

Organizational polices are the course of action, methodologies, arrangements, structures and systems. It basically explains that how many workers and employees working with the organization. It has been evident that decisive methodologies and systems are the basic tool for employee engagement and the conceivable achievement of the business destinations. Basic course of action and strategies may be decision making, flexi-timing, work life balance, and sensible game plans. According to Macey and Schneider (2008), selection and recruitment polices has a significant impact on employee engagement and their commitment. According to Richman (2006) argued in term of relationship that sophisticated work-life system, polices are positive impact on engagement. Distinctive studies by other researchers Ramlall (2008), Woodruffe (2005) have underscored the supremacy of various techniques and strategies that support work life balance and that kind of balancing environment is also effective for engagement.

\section{Workplace}

Workplace is another multi-dimensional element to measure engagement. According to researchers Harter et al. (2002) prosperity is characterized as "all the things that are important to how we think about and experience our lives" and in this way, prosperity turns into the most essential measure for assessing the impact of organization on his workers. Another research Perrin (2003) indicates the worth of wellbeing that is most crucial element of engagement is top management concentrates into their subordinates.

\section{Employee Performance}

Traditionally, work performance was evaluated in terms of the proficiency with which an employee performed the tasks that were identified in his or her job description. The changing nature of work and organizations, however, has challenged the traditional views of work performance and led supervisors and managers to place increasingly complex demands on employees (Griffin, Neal, \& Parker, 2007). Today, managers and supervisors expect their em- 
ployees to exceed the boundaries of their job description and show proactive work performance which can be characterized by proactive behaviors such as individual innovation and feedback inquiry that represent employees' selfinitiated, anticipatory actions to change and improve a certain situation or themselves. Performance of the any employee demonstrates monetary or non-monetary is directly related with the result of an employee enhanced performance in organization and well-being. According to many researchers Christian et al. (2011), Fleming and Asplund (2007), Holbeche and Springett (2004), Kompaso and Sridevi (2010), Leiter and Bakker (2010), Macey and Schneider (2008), Rich et al. (2010), Richman (2006), Ramlall (2008), a diversified approach toward improve worker execution is refining and focus on worker engagement. Similarly, the nearness of abnormal states to engagement that upgrades performance in terms of task execution, organizational behavior, profitability, voluntary effort, overload of work, over time of working hours, psychological and customer satisfaction.

\section{Work Practices}

HR practices is a tool through which it can be measured for the level of perceptions, mode of attitudes, and guided actions of employees (Wright, McMahan, \& McWilliams, 1994). Therefore, they conclude that role of HR practices is crucial tool and can't be denied. Another study found different thoughts as HPWPs and employee participation is uncertain except HPWPs structure and mechanism which are supportive toward employee participation (Shore \& Martin, 1989).

In addition, HR practice is measured as a fundamental key factor that affect performance (Guzzo \& Noonan, 1994; Jeung, 2011; Kaarsemaker \& Poutsma, 2006; Rousseau \& Greller, 1994; Rousseau \& Wade-Benzoni, 1994; Sims, 1994; Welch, 2011). According to Kaarsemaker and Poutsma (2006), Kramar (2014) HR practices are directly influence employee perception, commitment to achieve result and behavior. According to Leiter and Bakker (2010) he said that employees interpret deeds and activities of organization as per arrangements of organization himself. Eisenberger, Fasolo, and Davis-LaMastro (1990) further concluded that whenever employee realize that management is positive and dedicated to employee friendly $\mathrm{HR}$ practices then they believe that organization is loyal with them.

Consequently, HR practices might be a crucial element which play vital role between employee commitment and organizational development. A relationship of any employ- ees toward organization created via HR activities. For example, recruitment of employees, timely performance assessment, training and development program, and other employee well-being initiatives (Rousseau \& Greller, 1994). Henceforth, HR practices play very important role as a communicator, and determine the strength of relationship (Rousseau \& Wade-Benzoni, 1994).

\section{Work Engagement and Work Performance}

Saks (2006) categorized employee engagement into three components (i.e., cognitive, emotional, and behavioral) which are linked with performance of individual. Shuck, Reio Jr, and Rocco (2011) indicates that higher the engagement higher the performance of employees toward competitive advantage along with wide range of career growth. According to Welch (2011) this researcher also share this contribution, similar like (Shuck et al., 2011), to higher the level of engagement because it will stretches motivation toward worker efficacy, creativity and help to compete with market problems.

Bakker, Demerouti, and Euwema (2005) demonstrate (JD-R Model) "Job Demands Resources Model". According to this, work engagement has a great significant influence on job performance and also on employees. The indication concerning the precursors and outcomes related toward work engagement could be fixed on JD-R model. By structuring JD-R model, they outlined model based on assumptions of researchers. The first assumption stands for job resources such as, supportive by colleagues and managers in social influence, feedback of performance, talent diversity, and independence by work. The second assumption of model refers to same point that job resources turn out to be additional force that increases the potential of motivation level. As the workers are provoked through high job demands, for example, (work capacity, emotive demands, and psychological demands). Additionally, JD-R model create a linkage between job and personal resources (Xanthopoulou, Bakker, Demerouti, \& Schaufeli, 2007). Personal resources possibly stand with in-dependable side of work engagement. Hence, those who get top score on hopefulness, self-effectiveness and efficiency, flexibility and self-respect are sound components towards their activate job resources, usually engaged into their work. The model of JD-R illustrated in Figure 2 represent linkage between work engagement and performance. Researchers adopt the job and personal resources individually that help to predict work engagement. Moreover, job and personal resources mostly have significant influence on level of engagement once higher the job demand, there is a positive impact on job performance. Employees 
who are highly engaged produce their own particular resources and closely engaged and produce an encouraging result.

According to Shuck et al. (2011) the researcher who conducted a study among goods and service sector concludes that highly engaged employees perform well instead of lightly engaged employees. Slåtten and Mehmetoglu (2011) suggest that employee engagement thought to be a crucial factor toward creative work performance. In addition, engagement level has two phases, one phase is disagreeably associated to enervation and other phase is certainly linked to employee well-being and high involvement between organization and between performances (Alderfer, 1972). Many other researcher(s) and their studies have concluded that there is a strong direct affiliation of higher level of employee engagement and business performance consequences corresponding to employee retaining, customer satisfaction, efficiency, effectiveness, client devotion and security (Baumruk, 2006; Buckingham \& Coffman, 2014; Coffman, Kundu, \& Wootters, 2000; Ellis \& Sorensen, 2007; Perrin, 2003).

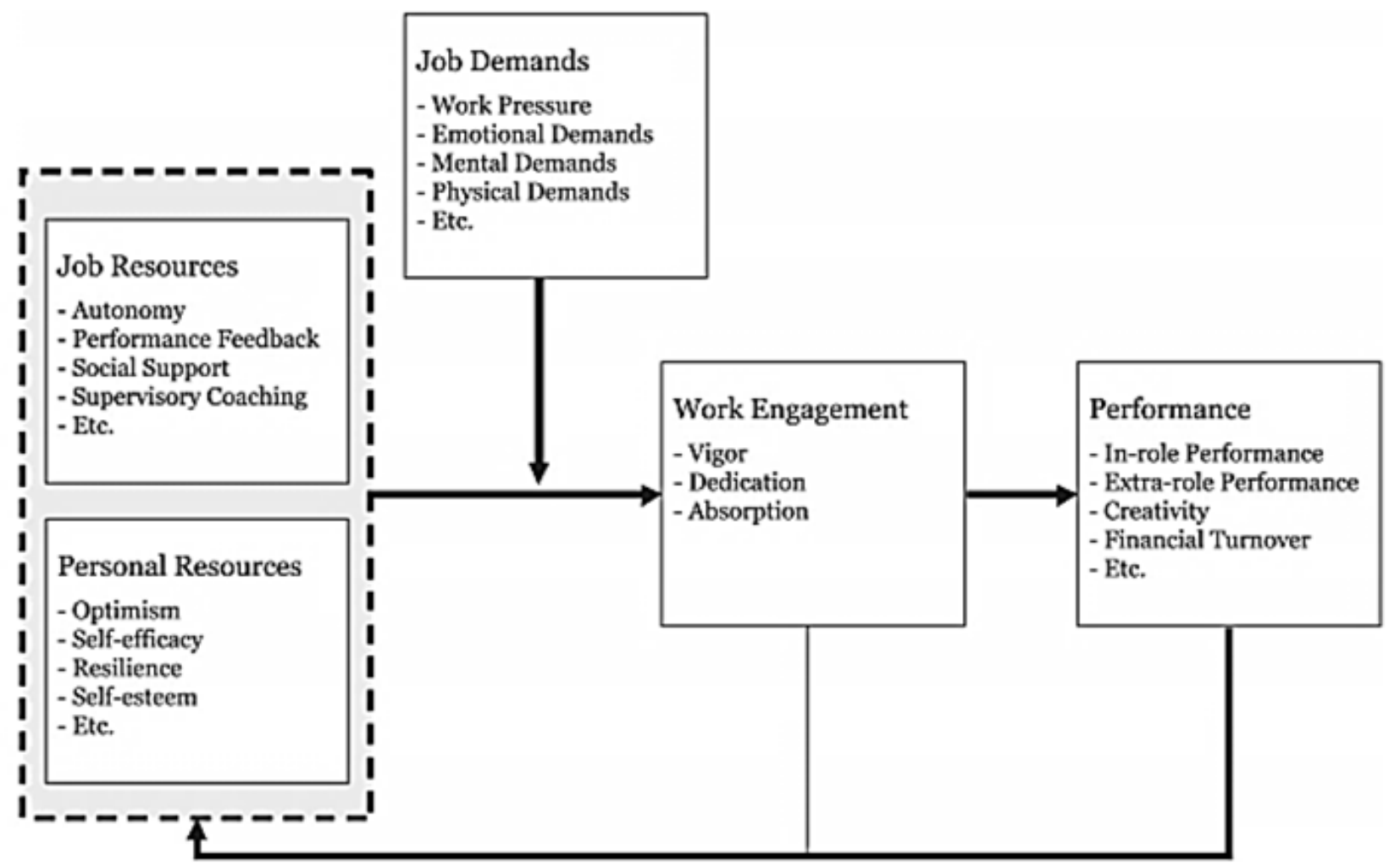

FIGURE 3. The JD-R model of work engagement (Source: (Bakker, Hakanen, Demerouti, \& Xanthopoulou, 2007)

\section{Work Practices and Work Performance}

There is enough evidence regarding the strong power of HPWP on employee productivity (Kramar, 2014; Shih, Chiang, \& Hsu, 2013). For instance, HPWPs have positive connection with improved performance and creativity in organizational perspective. Accordingly to (Appelbaum, Bailey, Berg, Kalleberg, \& Bailey, 2000; O'Regan, 2011; Truss et al., 2011), there are key components of super performance. An organized enactment of HPWPs restructure the entire work structure. Whereas; well-defined HR practices is a key component to attain optimistic things with better working environment. Abbas, Raja, Darr, and Bouckenooghe (2014) , Harley (2002) specified that appropriate and systematic implementation of HRM practices which is directly aligned with performance of employee. HPWPs might be central point to inspire positive performance and increase trustworthiness among the employees. Moreover, other group of researchers have said that there is one way of increasing performance through upgradation of job. HPWS comprises three ultimate thoughts i.e., enrichment of the job, authorizing the employees and reformation of work progression.

\section{Conceptual Framework}

Concerning the literature review the conceptual framework has been developed. The framework emphases on the work engagement \& work practices that effect on work performance. There are three variables that are scrutinized in this research which are below: 


\section{INDEPENDABLE VARIABLES}

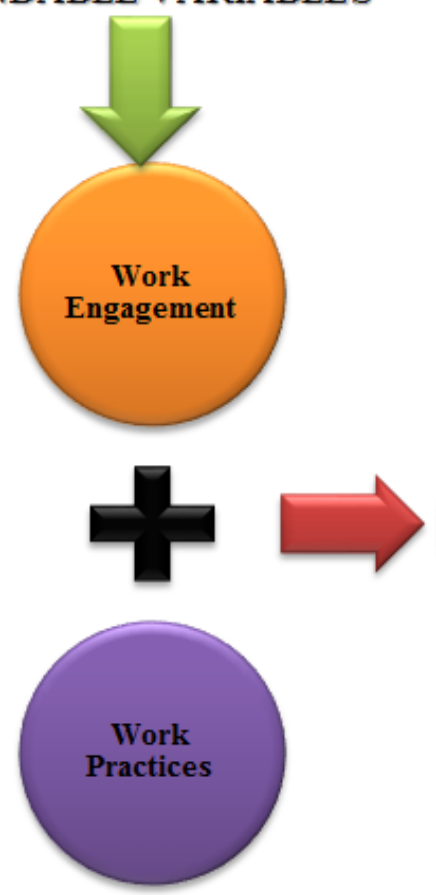

FIGURE 4. Conceptual framework

\section{RESEARCH METHODOLOGY}

\section{Research Philosophy}

The research philosophy means from different types of research techniques the most commonly used quantitative method is applied in this research for examining toward assessing work engagement, work practices and work performance in banks.

\section{Research Approach}

In this research, structured close ended questionnaire is circulated among participants to gather primary data.

\section{Sample Size}

The population of this study consists of employees of Banks. The data was collected from employees of different banks and on different hierarchical positions. The sample size for this study is 150 as it is going to target employees from various banks.

\section{DEPENDABLE VARIABI}

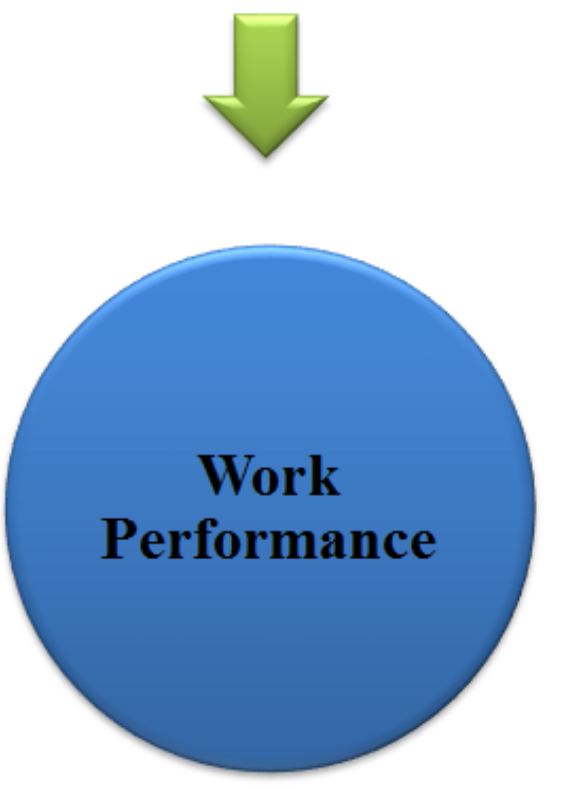

\section{Sample Techniques}

Using convenience method for sampling the requirements of research will be met. The technique that has been used is quantitative research.

\section{Data Collection Method}

This research was conducted through primary source, such as questionnaires were distributed among 150 employees of banking sector of Pakistan through online Google Form and in printed form questionnaire from which (127) responses were received.

\section{Data Analysis}

Data is analyzed by using of software Statistical Package for the Social Sciences (IBM SPSS 20). The Following test were applied in this study:

- Descriptive

- Reliability \& Validity Testing

- Regression Analysis

- Correlation Analysis

Summary of research instrument

\begin{tabular}{llll}
\hline \hline Variable & Source & No. of Items & Scale \\
\hline Work Engagement & Abu Bakar, R. (2013) & 12 & 6 \\
Work Performance & Shore, L. M., \& Martin, H. J. (1989) & 16 & 6 \\
Work Practices & Abu Bakar, R. (2013) & 18 & 6 \\
\hline \hline
\end{tabular}




\section{DATA ANALYSIS}

This part comprises the result of the research which was conducted at various banks. The nature of research is quantitative which is used to assess the effect of independent variables on dependent variable. There are two parts in the questionnaire, first part was for personal categorical data analysis of respondent's questions and the second part is for research questions.

\section{Personal Categorical Data Analysis}

It's clear that the above Age Table 2 describes that respondent describe the percentage of the age of the gender, the respondents that are selected for the survey test are from various ages so the above data gives us the estimation of the ages of that participants, $37.0 \%$ are Less than 25 age group, $52.0 \%$ are from $25-35$ age group, $11.0 \%$ are from $36-45$ age group.

TABLE 2. Summary of Personal Categorical Information

\begin{tabular}{|c|c|c|c|c|c|}
\hline & & & Age & & \\
\hline & & Frequency & Percent Valid Percent & Cumulative Percent & \\
\hline \multirow[t]{4}{*}{ Valid } & Less than 25 & 47 & 37.0 & 37.0 & 37.0 \\
\hline & $25-35$ & 66 & 52.0 & 52.0 & 89.0 \\
\hline & $36-45$ & 14 & 11.0 & 11.0 & 100.0 \\
\hline & Total & 127 & 100.0 & 100.0 & \\
\hline
\end{tabular}

TABLE 3. Summary of Personal Categorical Information

\begin{tabular}{llllll}
\hline \hline \multicolumn{5}{c}{ Gender } & \\
\hline \multirow{2}{*}{ Valid } & Male & 113 & 89.0 & Cumulative Percent & \\
& Female & 14 & 11.0 & 89.0 & 89.0 \\
& Total & 127 & 100.0 & 11.0 & 100.0 \\
\hline \hline
\end{tabular}

The Table 3 shows the data about the gender of the sample selected for the survey collection. The number of respondent were 127 from them $89.0 \%$ were male respondents and remaining $11.0 \%$ were female respondents. It also shows most of the male are the participants.

The Table 4 is describing about the Qualifications of partic- ipants. In this table, you can see the participants are selected from different qualifications on the random basses. The number of the Employees belongs to different qualification. Graduation is the peak percentage $54.3 \%$ that shows the strength of the Employees that have participated in the survey.

TABLE 4. Summary of Personal Categorical Information

\begin{tabular}{|c|c|c|c|c|c|}
\hline \multicolumn{6}{|c|}{ Qualification } \\
\hline & & Frequency & Percent Valid Percent & Cumulative Percent & \\
\hline \multirow[t]{5}{*}{ Valid } & Intermediate & 2 & 1.6 & 1.6 & 1.6 \\
\hline & Graduation & 69 & 54.3 & 54.3 & 55.9 \\
\hline & MS/M.Phil & 54 & 42.5 & 42.5 & 98.4 \\
\hline & Doctorate & 2 & 1.6 & 1.6 & 100.0 \\
\hline & Total & 127 & 100.0 & 100.0 & \\
\hline
\end{tabular}

TABLE 5. Summary of Personal Categorical Information

\begin{tabular}{llllll}
\hline \hline \multicolumn{5}{c}{ Current Position } \\
\hline Valid & Frequency & Percent Valid Percent & Cumulative Percent \\
& Non-Managerial Level & 63 & 49.6 & 49.6 & 49.6 \\
& Supervisory Level & 41 & 32.3 & 32.3 & 81.9 \\
& Executive Level & 22 & 17.3 & 17.3 & 99.2 \\
& Top Management & 1 & .8 & .8 & 100.0 \\
& Total & 127 & 100.0 & 100.0 & \\
\hline \hline
\end{tabular}


The Table 5 describes the different level of Designations of participants. In this table, you can see that participants were from different level of positions in the banks. Majority were from Non-Managerial Level having 49.6\%.

TABLE 6. Summary of Personal Categorical Information

\begin{tabular}{|c|c|c|c|c|c|}
\hline & \multicolumn{5}{|c|}{ No of Years in Present Organization } \\
\hline & & Frequency & Percent Valid Percent & Cumu & \\
\hline \multirow[t]{5}{*}{ Valid } & 4 years and less & 87 & 68.5 & 68.5 & 68.5 \\
\hline & 5 to 7 years & 33 & 26.0 & 26.0 & 94.5 \\
\hline & 8 to 10 years & 5 & 3.9 & 3.9 & 98.4 \\
\hline & 11 years and above & 2 & 1.6 & 1.6 & 100.0 \\
\hline & Total & 127 & 100.0 & 100.0 & \\
\hline
\end{tabular}

Table 6 shows that number of years in the present organization there were participants who is working presently in banks last four years of joining. Majority is $68.5 \%$ who were working form last four years.

TABLE 7. Summary of Personal Categorical Information

\begin{tabular}{|c|c|c|c|c|c|}
\hline & & & $\begin{array}{l}\text { Past } 12 \text { Months Abser } \\
\text { Work }\end{array}$ & & \\
\hline & & Frequency & Percent Valid Percent & Cumulative Percent & \\
\hline \multirow[t]{5}{*}{ Valid } & Less than 7 days & 97 & 76.4 & 76.4 & 76.4 \\
\hline & 7 to 15 days & 25 & 19.7 & 19.7 & 96.1 \\
\hline & 16 to 30 days & 4 & 3.1 & 3.1 & 99.2 \\
\hline & More than 1 month & 1 & .8 & .8 & 100.0 \\
\hline & Total & 127 & 100.0 & 100.0 & \\
\hline
\end{tabular}

Table 7 describes the absenteeism ratio of participants who was less absent, Majority were absent less than 7 days having $76.4 \%$.

As per Table 8, describes the various income range of participants, Majority ratio were 20,001-40,000 which is $51.2 \%$, second ratio were Less than 20,000 which is $22.8 \%$, third ratio were from $40,001-80,000$ which is $15.7 \%$, it concludes that major participants were from 20,001-40,000 income range.

As per Table 8 it describes the reason of changing job, Ma- jority participants were Never Changed their job they are still working in the same bank which is $30.7 \%$ ratio, participants who changed job due to salary is $28.3 \%$, participants who changed job due to Outlook on career is $21.3 \%$.

As per Table 10 it shows the frequency of changing job, Participants were Never changed their job which is $30.7 \%$, Majority participants were changed their job 1 to 3 times which represent major portion $62.2 \%$.

As per Table 11 its represent the mostly participants were belonging to Private banks which is 96.9

TABLE 8. Summary of Personal Categorical Information

\begin{tabular}{llllll}
\hline \hline \multicolumn{5}{c}{ Monthly Income } \\
\hline Valid & Less than 20,000 & 29 & Percent Valid Percent & Cumulative Percent \\
& 20,001 to 40,000 & 65 & 22.8 & 22.8 & 22.8 \\
& 40,001 to 80,000 & 20 & 15.7 & 51.2 & 74.0 \\
80,001 to 100,000 & 6 & 4.7 & 15.7 & 89.8 \\
100,001 to 120,000 & 5 & 3.9 & 4.7 & 94.5 \\
120,001 and above & 2 & 1.6 & 3.9 & 98.4 \\
Total & 127 & 100.0 & 1.6 & 100.0 \\
\hline \hline
\end{tabular}


TABLE 9. Summary of Personal Categorical Information

\begin{tabular}{|c|c|c|c|c|c|}
\hline & & & $\begin{array}{l}\text { If you have change job } \\
\text { in the past (from differ- } \\
\text { ent or same organiza- } \\
\text { tion), please state your } \\
\text { reason (s) for changing } \\
\text { job }\end{array}$ & & \\
\hline & & Frequency & Percent Valid Percent & Cumulative Percent & \\
\hline \multirow[t]{10}{*}{ Valid } & Never Changed & 39 & 30.7 & 30.7 & 30.7 \\
\hline & Salary & 36 & 28.3 & 28.3 & 59.1 \\
\hline & Poor supervision or leadership & 2 & 1.6 & 1.6 & 60.6 \\
\hline & Nature of job & 8 & 6.3 & 6.3 & 66.9 \\
\hline & Promotion & 10 & 7.9 & 7.9 & 74.8 \\
\hline & Organizational culture & 3 & 2.4 & 2.4 & 77.2 \\
\hline & Follow collegeagues & 1 & .8 & .8 & 78.0 \\
\hline & Future Outlook on career & 27 & 21.3 & 21.3 & 99.2 \\
\hline & Family issues & 1 & .8 & .8 & 100.0 \\
\hline & Total & 127 & 100.0 & 100.0 & \\
\hline
\end{tabular}

TABLE 10. Summary of Personal Categorical Information

\begin{tabular}{llllll}
\hline \hline & & $\begin{array}{l}\text { How many times have } \\
\text { you changed job }\end{array}$ & & \\
\hline & & Frequency & Percent Valid Percent & Cumulative Percent & \\
\hline Valid & Never & 39 & 30.7 & 30.7 & 30.7 \\
& 1 to 3 Times & 79 & 62.2 & 62.2 & 92.9 \\
& 4 to 6 times & 9 & 7.1 & 7.1 & 100.0 \\
& Total & 127 & 100.0 & 100.0 & \\
\hline \hline
\end{tabular}

TABLE 11. Summary of Personal Categorical Information

\begin{tabular}{llllll}
\hline \hline & & \multicolumn{2}{l}{$\begin{array}{l}\text { My organization belongs } \\
\text { to the }\end{array}$} & & \\
\hline & & Frequency & Percent Valid Percent & Cumulative Percent & \\
\hline Valid & Private & 123 & 96.9 & 96.9 & 96.9 \\
& Public & 4 & 3.1 & 3.1 & 100.0 \\
& Total & 127 & 100.0 & 100.0 & \\
\hline \hline
\end{tabular}

\section{Reliability Testing}

\section{Interpretation of reliability test}

To analyze and recognize the reliability and consistency of questionnaire, we used reliability tests and Cronbach alpha to get the results from the findings. We used 12 statements for our dependent variable Work Performance, 16 statements for first independent variable Work Engagement and 18 statements for second

TABLE 12. Results of reliability test (Cronbach's Alpha test)

\begin{tabular}{llllll}
\hline \hline & & \multicolumn{3}{l}{ Reliability Statistics } \\
\hline Variable & Cronbach's Alpha & $\begin{array}{l}\text { Cronbach's Alpha } \\
\text { Based on Stan- } \\
\text { dardized Items }\end{array}$ & Result \\
\hline Work engagement & .905 & .910 & 16 & Good \\
Work performance & .925 & .927 & 12 & Good \\
Work practices & .940 & .944 & 18 & Good \\
\hline \hline
\end{tabular}


independent variable Work Practices. As per above table presented that work performance, work engagement and work practices are having a high reliability and consistency as Cronbach's alpha for these three variables are $.925, .905$ and .940 respectively. All above results lies within the range of good.

\section{Regression Analysis} Interpretation of model summary test

As per above Table 12 concludes that the $\mathrm{R}$ square is .665 which indicates that means the model showed $66.5 \%$ variation of dependent variable (Work Performance) which is explained by the independent variables (Work Engagement).

TABLE 13. Results of regression test (Model summary)

\begin{tabular}{lllll}
\hline \hline & \multicolumn{3}{c}{ Model Summary } \\
\hline Model & $\boldsymbol{R}$ & $\boldsymbol{R}$ Square & Adjusted $\boldsymbol{R}$ Square & Std. Error of the Estimate \\
\hline 1 & $.816^{\mathrm{a}}$ & .665 & .662 & .45850 \\
\hline \hline
\end{tabular}

a. Predictors: (Constant), Work Engagement

b. Dependable variable: Work performance

TABLE 14. Result of regression test (Anova)

\begin{tabular}{llllll}
\hline \hline & & \multicolumn{3}{c}{ ANOVA $^{\mathbf{a}}$} & \\
\cline { 1 - 5 } Model & Sum of Squares & $\boldsymbol{d} \boldsymbol{f}$ & Mean Square $^{\text {F }}$ & $\boldsymbol{F}$ & Sig. \\
\hline 1 Regression & 52.188 & 1 & 52.188 & 248.253 & $.000^{\mathrm{b}}$ \\
Residual & 26.278 & 125 & .210 & & \\
Total & 78.466 & 126 & & & \\
\hline
\end{tabular}

a. Dependent Variable: Work Performance

b. Predictors: (Constant), Work Engagement

\section{Interpretation of ANOVA test}

As per above Table 14 The ANOVA model clarified that the independent variable (Work Engagement) is statistically significant to predict the dependent variable, where $F=$ 248.253 with the significance level of $0.000, p<0.05$.

TABLE 15. Results of regression test (Model summary)

\begin{tabular}{lllll}
\hline \hline Model & $\boldsymbol{R}$ & $\boldsymbol{R}$ Square & Adjusted $\boldsymbol{R}$ Square & Std. Error of the Estimate \\
\hline 1 & $.776^{\mathrm{a}}$ & .602 & .599 & .49963 \\
\hline \hline
\end{tabular}

a. Predictors: (Constant), Work Engagement

b. Dependable variable: Work performance

TABLE 16. Result of regression test (Anova)

\begin{tabular}{llllll}
\hline \hline Model & Sum of Squares & $\boldsymbol{d} \boldsymbol{f}$ & Mean Square & $\boldsymbol{F}$ & Sig. \\
\hline \multirow{2}{*}{ 1 Regression } & 47.262 & 1 & 47.262 & 189.329 & $.000^{\mathrm{b}}$ \\
& Residual & 31.204 & 125 & .250 & \\
& Total & 78.466 & 126 & & \\
\hline \hline
\end{tabular}

a. Dependent Variable: Work Performance

b. Predictors: (Constant), Work Engagement

\section{Interpretation of model summary test}

As per above table 15 concludes that the $\mathrm{R}$ square is .602 which indicates that means the model showed $60.2 \%$ variation of dependent variable (Work Performance) which is explained by the independent variables (Work Practices).

\section{Interpretation of ANOVA test}

As per above Table 16 The ANOVA model clarified that the independent variable (Work Practices) is statistically significant to predict the dependent variable, where $F=189.329$ with the significance level of $0.000, p<0.05$. 
TABLE 17. Results of Regression test (Coefficient)

\begin{tabular}{llllll}
\hline \hline \multirow{2}{*}{ Model } & \multicolumn{2}{l}{ Unstandardized Coefficients } & Standardized Coefficients & \multirow{2}{*}{ Sig. } \\
\cline { 2 - 4 } & $\beta$ & Std. Error & $\beta$ & & \\
\hline 1 (Constant) & .155 & .295 & & .525 & .600 \\
Work Engagement & .934 & .059 & .816 & 15.756 & .000 \\
\hline \hline
\end{tabular}

a. Dependent variable: Work performance

\section{Interpretation of coefficient test}

As per Table 17 describes the significance of variables. Significant value helps in knowing whether variable are good or not. The significance value of independent variable (Work Engagement) is less than 0.05 which indicates that these variable have positive impact on dependent variable.

TABLE 18. Results of Regression test (Coefficient)

\begin{tabular}{llllll}
\hline \hline Model & \multicolumn{2}{l}{ Unstandardized Coefficients } & Standardized Coefficients & \multirow{2}{*}{ Sig. } \\
\cline { 2 - 4 } & $\beta$ & Std. Error & $\beta$ & & \\
\hline 1 (Constant) & .362 & .323 & & 1.123 & .264 \\
Work Practices & .860 & .062 & .776 & 13.760 & .000 \\
\hline \hline
\end{tabular}

a. Dependent variable: Work performance

\section{Interpretation of coefficient test}

As per Table 18) describes the significance of variables. Signi value helps in knowing whether variable is good or not. The significance value of all independent variable (Work Practices) is less than 0.05 which indicates that these variables have positive impact on dependent variable.

\section{Correlation Analysis}

\section{Interpretation of correlation test}

The Pearson correlation was conducted to distinguish the effect of independent variables on dependent variables. The Table 19 has exposed the results that Performance in Banks has become weakly positive correlation between Work per- formance and Work Engagement where $r=.805$ with the sample size of 127 and significance value $=.000$ shows positive, weak relation between dependent and independent variables. It also shows that increase in Work Engagement will weakly increase the Work Performance.

Additionally, the correlation between other Work Practices and Work Performance also indicates the weak significant relationship between Work Performance and Work Practices., where $r=.776$ with the sample size of 127 and significance value $=.000$.

As a final point the results it confirmations that both independent variables have weak positive relationship with the dependent variable.

TABLE 19. Results of Regression test (Coefficient)

\begin{tabular}{lllll}
\hline \hline \multirow{2}{*}{ Work Engagement } & Work Engagement & Work Practices & Work Performance \\
\cline { 2 - 3 } & Pearson Correlation & 1 & $.805^{* *}$ & $.816^{* *}$ \\
& Sig. (2-tailed) & & .000 & .000 \\
& $N$ & 127 & 127 & 127 \\
\multirow{5}{*}{ Work Practices } & Pearson Correlation & $.805^{* *}$ & 1 & $.776^{* *}$ \\
& Sig. (2-tailed) & & .000 & .000 \\
& $N$ & 127 & 127 & 127 \\
& Pearson Correlation & $.816^{* *}$ & $.776^{* *}$ & 1 \\
& Sig. (2-tailed) & & .000 & .000 \\
& $N$ & 127 & 127 & 127 \\
\hline \hline
\end{tabular}

**. Correlation is significant at the 0.01 level (2-tailed)

\section{Hypothesis Testing Result}

Toward assessing relationship between work engagement, work practices and work performance. By evaluating the gathered data via using the software IBM SPSS version 20 . Pearson correlation and regression test are applied. As per basis of dependent variable and independent variables two 
hypotheses were made and the findings are as below.

\section{Hypothesis 1}

Ho1: There is no relationship between work engagement and work performance.

Ha1: There is significant relationship between work engagement and work performance.

\section{Interpretation}

On 5\% significance level the data provide satisfactory to accomplish that the null hypothesis is rejected, as the value of $\mathrm{p}$ is 0.00 which is less than 0.05 significance level. Hence, it is decided that there is positive relationship between work engagement and work performance.

\section{Hypothesis 2}

Ho2: There is no relationship between work practices and work performance.

Ha2: There is significant relationship between work practices and work performance.

\section{Interpretation}

On 5\% significance level the data provide satisfactory evidence to accomplish that the null hypothesis is rejected, as the value of $p$ is 0.00 which is less than 0.05 significance level. Hence, it is decided that there is positive relationship between work practices and work performance.

\section{DISCUSSION}

Up to the present time, there is no usually recognized definition for employee engagement. Most studies prove that feeling appreciated by administration there is a mutual communication between organization and employees, organization's awareness in employee's security, better work environment, flexible compensations, performance appraisal and giving more opportunities for employees to cultivate at the highest drivers of employee engagement.

The literature indicates that work engagement is directly linked with employee performance. Banks with engaged employees have higher employee performance because of they feel energetic, devoted and passionate toward their job. In contrast, banks with disengaged employees suffer less effectiveness, less productivity of and drain ability, less commitment by employees, dealing with absenteeism, have less goal oriented employees and lake of sense of personal accomplishment from work, major findings of engagement is positive relationship exists between them as per many researchers concludes (Christian et al., 2011; Fleming \& Asplund, 2007; Holbeche \& Springett, 2004; Kahn, 1990; Leiter \& Bakker, 2010; Macey \& Schneider, 2008; Rich et al., 2010; Richman, 2006; W. Schaufeli, 2012).

Furthermost studies highlighted purely the importance and constructive effects of various work practices and its key factors like Employee training and development, Reward policies, organizational polices, appraisal management system, employee empowerment and co-worker support, restructuring, that is directly associated towards employee performance, loyalty, creativity, results will remain to be central. The research findings showed that the employees working at banking sector which shown significant relationship between work practices and work performance as many researcher indicates by (Abbas et al., 2014; Appelbaum et al., 2000; Kompaso \& Sridevi, 2010; Kramar, 2014; Punia et al., 2014; Rousseau \& Greller, 1994). There are two results of our research first result is that work engagement on the other hand work practices which has positively, directly effect on the performance level of the employees especially in the banking sector.

\section{CONCLUSION}

This research was grounded on the quantitative data collected from the employees in Banks. The research was intended to get the finding of the impact work engagement level and work practices on work performance. Two independent variables; work engagement and work practices were gained from the literature review to distinguish the impact of these two variables on dependent variable work performance. In the direction of scrutiny, the data was collected by questionnaire and via Google online form questionnaire were distributed among 150 employees of various banks. The above analysis of the study emphasized the importance of employee high engagement and high involvement practices have the positive significant relationship between performances of the employees. This study exhibited that highest number of employees at Banks are involved with high level of engagement and high involvement work practices that were offered to them. As per the consequence identified that higher the work engagement and high involvement of work practices have strong direct linked with work performance. At the conclusions, as the result of the research decided that both high level of employee engagement and high level of work involvement has direct link with employee's performance.

\section{RECOMMENDATIONS}

There are several recommendations are suggested that ought to be careful by the Top management of Banks to retain their workforces more productive and improve performance through engagement and practices. Banks should 
adapt new strategies and practices to keep their manpower engaged. High levels of employee engagement in an organization are linked to superior business performance and employee performance as well. Provide effective training programs. Provide entirely new employees with appropriate training about job. Ensure them that each employee aware about his job duties and the most effective method of performing that. After the developments for realization the work completed, they'll have the capabilities to contribute their creative thoughts and be effective at completing task done. Be that as it may, don't tragically think that training is a single-time thing. Training must remain ongoing process so that employees keep to develop their skills and knowledge. Ongoing process of training is the best approach to consistently enhance employee performance. Open communication downward to upward. You must clearly have understood that what is most important to the employee you can get feedback via survey, suggestions box. Give them autonomy to express their opinions and ideas. Show them that you are sincerely concerned about your employee's feelings and use social media as a communications tool to build engagement. Build team environment High employee engagement is believing that how employees cooperate and communicate with respectively and take interest in a team work. Support your staffs in their work and growth Support your employees for their contribution toward work and appreciate their efforts to perform task and show encourage to further growth in career. Give Incentives either intrinsic or extrinsic Bosses who wish to their employees should be engaged you need to provide Incentives must be according to their contribution toward working hours and efforts that who is actively participating and must be according to their nature of work.

\section{LIMITATIONS OF STUDY}

The limits for this research would be motivation for future research. It was a quantitative research where all data were collected within given particular time. The research was conducted for the academic purposes at MBA level. The primary source of research was only accessible in one city with the sample size of 150 from them 127 responses were received at the end. Similarly, this study is limited to financial sector of Pakistan, further study may be focus on another sector of Pakistan. The research was individual founded on two independent variables and their relationship with employee performance.

\section{AREAS OF FUTURE RESEARCH}

To continue this study for the further future research, the future studies may consider additional level of engagement or whither dimensions of HR practices included teamwork, two-way communication, human development, selection and recruitment, employment security, internal career/promotion opportunities, single status and harmonization, quality/involvement, job design and also with extended sample size via probability sampling technique.

\section{REFERENCES}

Abbas, M., Raja, U., Darr, W., \& Bouckenooghe, D. (2014). Combined effects of perceived politics and psychological capital on job satisfaction, turnover intentions, and performance. Journal of Management, 40(7), 1813-1830.

Alderfer, C. P. (1972). Existence, relatedness, and growth: Human needs in organizational settings. New York, NY: Free Press.

Anitha, J. (2014). Determinants of employee engagement and their impact on employee performance. International journal of Productivity and Performance Management, 63(3), 308-323. doi:https://doi.org/10.1108/ijppm-01-2013-0008

Appelbaum, E., Bailey, T., Berg, P. B., Kalleberg, A. L., \& Bailey, T. A. (2000). Manufacturing advantage: Why high-performance work systems pay off. Ithaca, NY: Cornell University Press.

Bakker, A. B., Demerouti, E., De Boer, E., \& Schaufeli, W. B. (2003). Job demands and job resources as predictors of absence duration and frequency. Journal of vocational Behavior, 62(2), 341-356. doi:https://doi.org/10.1016/ s0001-8791(02)00030-1

Bakker, A. B., Demerouti, E., \& Euwema, M. C. (2005). Job resources buffer the impact of job demands on burnout. Journal of occupational health psychology, 10(2), 170-180. doi:https://doi.org/10.1037/1076-8998.10.2.170

Bakker, A. B., Hakanen, J. J., Demerouti, E., \& Xanthopoulou, D. (2007). Job resources boost work engagement, particularly when job demands are high. Journal of Educational Psychology, 99(2), 274-284.

Bakker, A. B., Schaufeli, W. B., Leiter, M. P., \& Taris, T. W. (2008). Work engagement: An emerging concept in occupational health psychology. Work \& Stress, 22(3), 187-200. doi:https://doi.org/10.1080/02678370802393649

Baumruk, R. (2006). An interview by bob gorman jr. Strategic HR Review, 15, 47-54.

Buckingham, M., \& Coffman, C. (2014). First, break all the rules: What the world's greatest managers do differently. New York, NY: Simon and Schuster. 
Cardy, R. L. (2004). Performance management: Concepts. Retrieved from https://goo.gl/j1NZ3V (accessed on 24 October 2008)

Cartwright, S., \& Holmes, N. (2006). The meaning of work: The challenge of regaining employee engagement and reducing cynicism. Human Resource Management Review, 16(2), 199-208. doi:https://doi.org/10.1016/j.hrmr.2006.03.012

Chong, C. Y., \& Lee, T. S. (2017). Employee retention and job performance attributes in private institutions of higher education. International Journal of Business and Administrative Studies, 3(5), 158-165. doi:https://doi.org/10.20469/ ijbas.3.10001-5

Christian, M. S., Garza, A. S., \& Slaughter, J. E. (2011). Work engagement: A quantitative review and test of its relations with task and contextual performance. Personnel Psychology, 64(1), 89-136. doi:https://doi.org/10.1111/j.1744-6570 .2010.01203.x

Coffman, V., Kundu, J., \& Wootters, W. K. (2000). Distributed entanglement. Physical Review, 61(5), 052306.

Deci, E. L., \& Ryan, R. M. (1987). The support of autonomy and the control of behavior. Journal of Personality and Social Psychology, 53(6), 1024-1037. doi:https://doi.org/10.1037//0022-3514.53.6.1024

Delery, J. E., \& Doty, D. H. (1996). Modes of theorizing in strategic human resource management: Tests of universalistic, contingency, and configurational performance predictions. Academy of Management Journal, 39(4), 802-835. doi: https://doi.org/10.5465/256713

Eisenberger, R., Fasolo, P., \& Davis-LaMastro, V. (1990). Perceived organizational support and employee diligence, commitment, and innovation. Journal of Applied Psychology, 75(1), 51. doi:https://doi.org/10.1037//0021-9010.75.1.51

El-Ghalayini, Y. (2016). The effects of high performance work system on employee attitudes: A study of international organization. Journal of Administrative and Business Studies, 2(5), 248-263. doi:https://doi.org/10.20474/jabs-2.5.5

Ellis, C. M., \& Sorensen, A. (2007). Assessing employee engagement: The key to improving productivity. Perspectives, 15(1), 1-9. doi:https://doi.org/10.5267/j.msl.2015.11.006

Fleming, J. H., \& Asplund, J. (2007). Human sigma: Managing the employee-customer encounter. New York, NY: Simon and Schuster.

Fred, L., \& Suzanne, J. P. (2002). Employee engagement and manager self-efficacy. The Journal of Management Development, 21(5), 376-387. doi:https://doi.org/10.1108/02621710210426864

Griffin, M. A., Neal, A., \& Parker, S. K. (2007). A new model of work role performance: Positive behavior in uncertain and interdependent contexts. Academy of Management Journal, 50(2), 327-347. doi:https://doi.org/10.5465/amj.2007 .24634438

Guzzo, R. A., \& Noonan, K. A. (1994). Human resource practices as communications and the psychological contract. Human Resource Management, 33(3), 447-462. doi:https://doi.org/10.1002/hrm.3930330311

Harley, B. (2002). Employee responses to high performance work system practices: An analysis of the awirs 95 data. The Journal of Industrial Relations, 44(3), 418-434. doi:https://doi.org/10.1111/1472-9296.00057

Harter, J. K., Schmidt, F. L., \& Hayes, T. L. (2002). Business-unit-level relationship between employee satisfaction, employee engagement, and business outcomes: A meta-analysis. Journal of applied psychology, 87(2), 268-279. doi:https:// doi.org/10.1037//0021-9010.87.2.268

Hewitt Associates LLC. (2004). Research brief: Employee engagement higher at double-digit growth companies. Retrieved from https://goo.gl/vsCGZ6 (accessed on 21 March 2011.)

Holbeche, L., \& Springett, N. (2004). In search of meaning at work. Citeseer. Retrieved from https://goo.gl/iigzLq (accessed on 23 October 2017)

Ivancevich, J. M., Matteson, M. T., Freedman, S. M., \& Phillips, J. S. (1990). Worksite stress management interventions. American Psychologist, 45(2), 252-257. doi:https://doi.org/10.1037//0003-066x.45.2.252

Jeung, C.-W. (2011). The concept of employee engagement: A comprehensive review from a positive organizational behavior perspective. Performance Improvement Quarterly, 24(2), 49-69. doi:https://doi.org/10.1002/piq.20110

Kaarsemaker, E. C., \& Poutsma, E. (2006). The fit of employee ownership with other human resource management practices: Theoretical and empirical suggestions regarding the existence of an ownership high-performance work system. Economic and Industrial Democracy, 27(4), 669-685. doi:https://doi.org/10.1177/0143831x06069009

Kahn, W. A. (1990). Psychological conditions of personal engagement and disengagement at work. Academy of Management Journal, 33(4), 692-724. doi:https://doi.org/10.2307/256287 
Kompaso, S. M., \& Sridevi, M. S. (2010). Employee engagement: The key to improving performance. International Journal of Business and Management, 5(12), 89-94. doi:https://doi.org/10.5539/ijbm.v5n12p89

Kramar, R. (2014). Beyond strategic human resource management: Is sustainable human resource management the next approach? The International Journal of Human Resource Management, 25(8), 1069-1089. doi:https://doi.org/10 $.1080 / 09585192.2013 .816863$

Leiter, M. P., \& Bakker, A. B. (2010). Work engagement: A handbook of essential theory and research. Abingdon, UK: Psychology Press.

Locke, E., \& Taylor, M. (1990). Stress, coping, and the meaning of work. In A., Nord, W. R (Eds.), Meanings of occupational. Lexington, KY: Lexington Books.

Macey, W. H., \& Schneider, B. (2008). The meaning of employee engagement. Industrial and Organizational Psychology, 1(1), 3-30. doi:https://doi.org/10.1111/j.1754-9434.2007.0002.x

Maslach, C., \& Leiter, M. P. (1997). The truth about burnout: How organizations cause stress and what to do about it. San Francisco, CA: Willey Online.

May, D. R., Gilson, R. L., \& Harter, L. M. (2004). The psychological conditions of meaningfulness, safety and availability and the engagement of the human spirit at work. Journal of Occupational and Organizational Psychology, 77(1), 11-37. doi:https://doi.org/10.1348/096317904322915892

Mone, E. M., \& London, M. (2018). Employee engagement through effective performance management: A practical guide for managers. Abingdon, UK: Routledge.

Murphy, T. H., \& Margulies, J. (2004). Performance appraisals. In Conference on ABA Labor and Employment Law Section, Equal Employment Opportunity Committee, California, CA.

Na Ayutthaya, J. S., Tuntivivat, S., \& Prasertsin, U. (2016). The effect of positive psychological capital and organizational climate on service quality: The mediation role of work engagement of hotel service employees in Ratchaburi province. Journal of Administrative and Business Studies, 2(4), 167-176. doi:https://doi.org/10.20474/jabs-2.4.3

O'Regan, J. K. (2011). Why red doesn't sound like a bell: Understanding the feel of consciousness. Oxford, UK: Oxford University Press.

Pahayahay, A. B., Asejo, N. R., Pangan, S. M., Dasig Jr., D. D., \& Panganiban Jr., A. S. (2017). A concurrent exploratory study on sectoral engagement model of an altruistic corporate social responsibility in bureau of jail management and penology. International Journal of Business and Economic Affairs, 2(2), 98-105. doi:https://doi.org/10.24088/ ijbea-2017-22003

Paradise, A. (2008). Learning influences employee engagement. Association for Talent Development, 62(1), 54-55.

Perrin, T. (2003). The 2003 towers perrin talent report. Understanding Employee Engagement, 1(R), 2009-2013.

Punia, B., Garg, N., \& Garg, N. (2014). An organisational analysis of high performance work practices. Asian Journal of Management, 5(3), 318-324. doi:https://doi.org/10.2139/ssrn.2693450

Ramlall, S. J. (2008). Enhancing employee performance through positive organizational behavior. Journal of Applied Social Psychology, 38(6), 1580-1600. doi:https://doi.org/10.1111/j.1559-1816.2008.00360.x

Rich, B. L., Lepine, J. A., \& Crawford, E. R. (2010). Job engagement: Antecedents and effects on job performance. Academy of Management Journal, 53(3), 617-635. doi:https://doi.org/10.5465/amj.2010.51468988

Richman, A. (2006). Everyone wants an engaged workforce how can you create it. Workspan, 49(1), 36-39.

Rousseau, D. M., \& Greller, M. M. (1994). Human resource practices: Administrative contract makers. Human Resource Management, 33(3), 385-401. doi:https://doi.org/10.1002/hrm.3930330308

Rousseau, D. M., \& Wade-Benzoni, K. A. (1994). Linking strategy and human resource practices: How employee and customer contracts are created. Human Resource Management, 33(3), 463-489. doi:https://doi.org/10.1002/hrm.3930330312

Saks, A. M. (2006). Antecedents and consequences of employee engagement. Journal of Managerial Psychology, 21(7), 600-619. doi:https://doi.org/10.1108/02683940610690169

Schaufeli, W. (2012). Work engagement: What do we know and where do we go? Romanian Journal of Applied Psychology, 14(1), 3-10.

Schaufeli, W. B., \& Bakker, A. B. (2010). Defining and measuring work engagement: Bringing clarity to the concept. Work Engagement: A Handbook of Essential Theory and Research, 4(67), 10-24. 
Schaufeli, W. B., Bakker, A. B., \& Van Rhenen, W. (2009). How changes in job demands and resources predict burnout, work engagement, and sickness absenteeism. Journal of Organizational Behavior, 30(7), 893-917. doi:https://doi.org/ $10.1002 /$ job.595

Schaufeli, W. B., Salanova, M., González-Romá, V., \& Bakker, A. B. (2002). The measurement of engagement and burnout: A two sample confirmatory factor analytic approach. Journal of Happiness Studies, 3(1), 71-92. doi:https://doi.org/ 10.1023/a:1015630930326

Schneider, K. J., \& May, R. (1995). The psychology of existence: An integrative, clinical perspective. New Tork, NY: Mcgraw-Hill Book Company.

Sharma, B., et al. (2015). The mediating role of employee engagement in the relationship between high performance work practices and job performance. Managment Review, 3(6), 56-70. doi:https://doi.org/10.2139/ssrn.2694991

Shih, H. A., Chiang, Y.-H., \& Hsu, C.-C. (2013). High performance work system and hon performance. Journal of Business Research, 66(4), 540-546. doi:https://doi.org/10.1016/j.jbusres.2012.01.002

Shore, L. M., \& Martin, H. J. (1989). Job satisfaction and organizational commitment in relation to work performance and turnover intentions. Human Relations, 42(7), 625-638. doi:https://doi.org/10.1177/001872678904200705

Shuck, B., Reio Jr, T. G., \& Rocco, T. S. (2011). Employee engagement: An examination of antecedent and outcome variables. Human Resource Development International, 14(4), 427-445. doi:https://doi.org/10.1080/13678868.2011.601587

Sims, R. R. (1994). Human resource management's role in clarifying the new psychological contract. Human Resource Management, 33(3), 373-382. doi:https://doi.org/10.1002/hrm.3930330306

Slåtten, T., \& Mehmetoglu, M. (2011). What are the drivers for innovative behavior in frontline jobs? a study of the hospitality industry in Norway. Journal of Human Resources in Hospitality \& Tourism, 10(3), 254-272. doi:https://doi.org/10 $.1080 / 15332845.2011 .555732$

Spector, P. E., Dwyer, D. J., \& Jex, S. M. (1988). Relation of job stressors to affective, health, and performance outcomes: a comparison of multiple data sources. Journal of Applied Psychology, 73(1), 11-19. doi:https://doi.org/10.1037// 0021-9010.73.1.11

Truss, K., Soane, E., Delbridge, R., Alfes, K., Shantz, A., \& Petrov, G. (2011). Employee engagement, organisational performance and individual well-being: exploring the evidence, developing the theory. New York, NY: Taylor \& Francis.

Viljevac, A., Cooper-Thomas, H. D., \& Saks, A. M. (2012). An investigation into the validity of two measures of work engagement. The International Journal of Human Resource Management, 23(17), 3692-3709. doi:https://doi.org/10.1080/ 09585192.2011 .639542

Wallace, L., \& Trinka, J. (2009). Leadership and employee engagement. Public Management, 91(5), 10-13. doi:https:// doi.org/10.1097/01.phh.0000285207.63835.50

Walumbwa, F. O., Avolio, B. J., Gardner, W. L., Wernsing, T. S., \& Peterson, S. J. (2008). Authentic leadership: Development and validation of a theory-based measure. Journal of Management, 34(1), 89-126. doi:https://doi.org/10.1177/ 0149206307308913

Warizin, H. (2017). Influence of individual characteristics and work environment on employee's motivation and performance. Journal of Administrative and Business Studies, 3(5), 212-220. doi:https://doi.org/10.20474/jabs-3.5.3

Welch, M. (2011). The evolution of the employee engagement concept: Communication implications. Corporate Communications: An International Journal, 16(4), 328-346. doi:https://doi.org/10.1108/13563281111186968

Woodruffe, C. (2005). They've got a job! what more could they want. Management Services, 49(3), 24-26.

Wright, P. M., McMahan, G. C., \& McWilliams, A. (1994). Human resources and sustained competitive advantage: A resourcebased perspective. International Journal of Human Resource Management, 5(2), 301-326. doi:https://doi.org/ $10.1080 / 09585199400000020$

Xanthopoulou, D., Bakker, A. B., Demerouti, E., \& Schaufeli, W. B. (2007). The role of personal resources in the job demands-resources model. International Journal of Stress Management, 14(2), 121-141. doi:https://doi.org/10.1037/ 1072-5245.14.2.121

Xu, J., \& Cooper Thomas, H. (2011). How can leaders achieve high employee engagement? Leadership \& Organization Development Journal, 32(4), 399-416. doi:https://doi.org/10.1108/01437731111134661 